\title{
Genetic analysis for anthocyanin and chlorophyll contents in rapeseed
}

\author{
Análise genética para antocianinas e de clorofila em sementes de colza
}

\author{
Wendong Dai, ${ }^{\text {II }}$ Teerayoot Girdthai ${ }^{*}$ Zesu Huang ${ }^{\text {II }}$ \\ Mariena Ketudat-Cairns ${ }^{\text {III }}$ Rong TangII Shaoming WangII
}

\section{ABSTRACT}

Rapeseed (Brassica napus L.) with purple-red leaf is a valuable resource for plant breeder. It was utilized in breeding program as a morphological marker, and the source of resistance gene to biotic or abiotic stress due to its anthocyanin content (AC). However, the inheritance of $A C$ and the correlation with chlorophyll content (CC) in rapeseed leaf are still unknown. This study aimed to investigate the gene action and heritability of $A C$ and $C C$ in a 10Zi006 $\times 10-4438$ rapeseed cross using generation mean analysis. The results indicated that $A C$ and $C C$ were controlled by main gene effect and non-allelic interactions. The AC was mainly controlled by genetic effect. However, the genetic effect and non-genetic effect were both important for CC. In addition, the total fixable gene effects was higher than unfixable gene effects for AC, but opposite results was found for $C C$. Both negative and positive correlations between $A C$ and $C C$ were obtained in different generations.

Key words: generation mean analysis, gene effect, genetic model, heritability.

\section{RESUMO}

Colza (Brassica napus L.) de folhas vermelhopúrpura é um recurso valioso para os produtores. Foi utilizada em programas de melhoramento como um marcador morfológico ao gene de resistência a estresses abióticos, bióticos ou devido ao seu teor de antocianinas (AC). No entanto, a herança da $A C$ e a correlação com o teor de clorofila (CC) na folha de colza ainda são desconhecidos. Este estudo teve como objetivo investigar a ação dos genes e hereditariedade da CA e CC em $10 \mathrm{ZiO06} \times 10$ 4438 colza, usando geração de análise. Os resultados indicaram que $C A$ e CC foram controladas por efeito do gene principal $e$ interacções não-alélicas. $O A C$ foi controlado principalmente por efeito genético. No entanto, os efeitos genético e não genético foram ambos importantes para CC. Além disso, o total de efeitos gênicos solucionáveis foi maior do que os efeitos de genes para $A C$, mas os resultados opostos foram encontrados para $C C$. Correlações negativas e positivas entre CA e CC foram obtidas em diferentes gerações.

Palavras-chave: análise de geração, gene, modelo genético, herdabilidade.

\section{INTRODUCTION}

Anthocyanin, a type of flavonoid pigments, is commonly responsible for orange red to violet blue color in plant tissues (TANAKA et al., 2008). It was mainly studied in horticultural crops due to some health benefits (SHIN et al., 2006; WILLIAMS et al., 2008; SINGH et al., 2011; LIANG et al., 2012; SABOLU et al., 2014). In addition, anthocyanin plays an important role as a morphological marker in hybrid rapeseed (WANG et al., 2007). In China, hybrid breeding is one of the most effective ways to increase seed yield. However, the false hybrid were often produced due to pollens contamination. Three-line GMS and CMS + SI (selfincompatibility) systems were suggested as an effective methods to cope this problem (SHEN et al., 2008). In addition, selection of restorer or temporary maintainer line with purple-red leaf for developing rapeseed hybrid have been recommended to identify the false $\mathrm{F}_{1}$ hybrid (WANG et al., 2007; WU et al., 2007). The rapeseed line 10-Zi006 with purple-red leaf had been successfully

\footnotetext{
ISchool of Crop Production Technology, Institute of Agricultural Technology, Suranaree University of Technology, Nakhorn Ratchasima, 30000, Thailand. E-mail: teerayoot@sut.ac.th. "Corresponding author.

IIGuizhou Institute of Oil Crops, Guiyang, 550006, People's Republic of China.

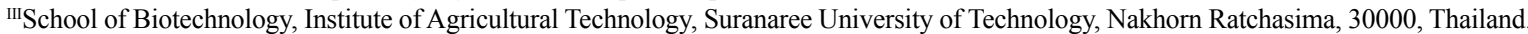
Received 04.18.15 Approved 09.25.15 Returned by the author 02.04.16 CR-2015-0564.R1
} 
developed by interspecific hybridization. This obvious color started at seedling stage, and the leaf will change to green color at bolting stage or full-blossom stage differed from line to line (WANG et al., 2007).

Moreover, anthocyanin was an important pigment in response to cold stress in winter rapeseed (SOLECKA et al., 1999), and in ameliorating environmental stresses induced by visible and UV-B radiation and drought conditions (CHALKERSCOTT, 1999). Therefore, development of rapeseed cultivars with high $\mathrm{AC}$ is very important role in increasing plant resistance to drought and cold stress which are the main limiting factors in rapeseed production. However, the possible effects of $\mathrm{AC}$ were confounded by the decrease of photochemical efficiency when CC loss in senescing leaves of Cornus sanguinea and Parthenocissus quinquefolia (MANETAS et al., 2011). In addition, a significant decrease of photosynthetic pigments simultaneous with an increase of AC was measured in poinsettia bract development (SLATNAR et al., 2013). Due to limited information available on gene action for AC and $\mathrm{CC}$ in rapeseed leaf, the objective of this research were to define the gene action for $\mathrm{AC}$ and $\mathrm{CC}$, and investigate the correlation between them for further hybrid breeding of rapeseed.

\section{MATERIALS AND METHODS}

Two inbred lines, 10-Zi006 with purplered leaf and 10-4438 with green leaf were crossed to generate the $F_{1}$ generation in 2010/2011. In 2011/2012, $F_{1}$ were selfed to develop $F_{2}$ generation and backcrossed to each parent to obtain $B_{1}$ and $\mathrm{B}_{2}$ generations, respectively. Six generations were evaluated using a randomized complete block design with 3 replications at GAAS (Guizhou Academy of Agriculture Sciences, Guiyang, China) in 2012/2013 and 2013/2014. All six generations were sowed in nursery plots and then transplanted into individual plot after 35 days. Each plot consisted of different numbers of row with $240 \mathrm{~cm}$ in length. Seelings were transplanted at an inter-row spacing of $45 \mathrm{~cm}$ and an intra-row spacing of $33.3 \mathrm{~cm}$ with two plants per hill. $\mathrm{P}_{1}, \mathrm{P}_{2}$ and $\mathrm{F}_{1}$ were grown in six rows for both years. $\mathrm{F}_{2}, \mathrm{~B}_{1}$ and $\mathrm{B}_{2}$ were represented by 27,21 and 12 rows in $2012 / 2013$, and represented by 21,12 and 12 rows in 2013/2014, respectively.

The top fully expanded leaf of each plant in six generations were measured for AC and $\mathrm{CC}$ at seedling stage. The measurement of total AC was performed by using photometric method (MEHRTENS et al., 2005). Total CC was determined by SPAD Chlorophyll Meter Reading (Minolta SPAD-502 plus, Osaka, Japan) and each leaf was measured five times in different parts to monitor the chlorophyll status.

A, B and C scaling test according to MATHER (1949) and HAYMAN \& MATHER (1955) were used for determination of absence or presence of non-allelic interactions. Joint scaling test proposed by CAVALLI (1952) was used to estimate the parameters of $\mathrm{m}, \mathrm{d}$ and $\mathrm{h}$, and test the goodness of fit of the additive-dominance model by $\chi^{2}$ testing. Estimation of six parameters were performed according to HAYMAN (1958). Broad sense and narrow sense heritability were estimated using the method outlined by WARNER (1952). R software was used for data analysis (R DEVELOPMENT CORE TEAM, 2015).

\section{RESULTS AND DISCUSSION}

The analysis of variance (Table 1) showed that $\mathrm{AC}$ was significant and $\mathrm{CC}$ was highly significant between years. The results indicated that both studied traits were significantly affected by the environment. This might be due to the environmental factors such as UV-A, UV-B, temperature, light intensity, nutrition and moisture regulated the synthesis of anthocyanin in leaves (LEE et al., 2003; SCHABERG et al., 2003; TOSSI et al., 2011; WANG et al., 2012). In addition, highly significant difference between generations on the traits were detected, especially between parental lines (Figure 1). Moreover, the environment (year) $\times$ generations interaction was significant for $\mathrm{AC}$ but not for $\mathrm{CC}$.

The scaling test and estimation of six parameters were presented in table 2 . The $t$-test between parents for both traits indicated that the data was suitable for genetic analysis. The scaling

Table 1 - Analysis of variance for anthocyanin and chlorophyll contents of $\mathrm{P}_{1}, \mathrm{P}_{2}, \mathrm{~F}_{1}, \mathrm{~F}_{2}, \mathrm{~B}_{1}$ and $\mathrm{B}_{2}$ generations evaluated in $2012 / 13$ and $2013 / 14$ at Guiyang, Southwest of China.

\begin{tabular}{llll}
\hline Source of variation & df & \multicolumn{2}{c}{-------Mean square--------- } \\
& & AC & CC \\
\hline Replications & 2 & 0.002 & 0.711 \\
Years & 1 & $0.232^{*}$ & $203.633^{* *}$ \\
Generations & 5 & $3.634^{* *}$ & $60.871^{* *}$ \\
Years $\times$ Generations & 5 & $0.024^{*}$ & 0.322 \\
Error & 22 & 0.006 & 0.919 \\
Total & 35 & & \\
\hline
\end{tabular}

$\mathrm{AC}=$ Anthocyanin content; $\mathrm{CC}=$ Chlorophyll content; ${ }^{*} \mathrm{P}<0.05$; ${ }^{* *} \mathrm{P}<0.01$; 


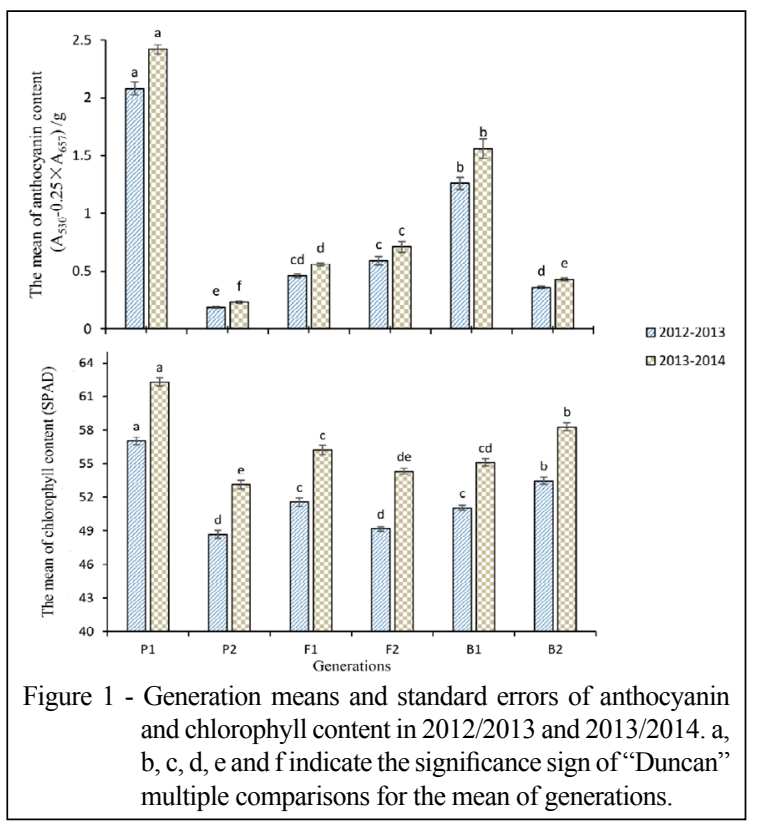

test indicated that additive-dominance model were inadequate for $\mathrm{AC}$ and $\mathrm{CC}$ and revealed of non-allelic interaction. Joint scaling test confirmed absolutely the results with highly significant of $\chi^{2}$ vales in the three parameter models. Positive additive effect [d] was highly significant for AC. Contrarily, negative additive effect for CC was also significant in both seasons. Dominance effect $[\mathrm{h}]$ was not significant for $\mathrm{AC}$ but positive effect was highly significant for $\mathrm{CC}$ in both 2013 and 2014. High significant additive $\times$ additive epistatic effects [i] were detected for AC and $\mathrm{CC}$ in both years. Additive $\times$ dominance effect [j] was found to be negative and high significant for $\mathrm{CC}$ but was not significant for $\mathrm{AC}$ in both years. Dominance $\times$ dominance effect [1] were negative and significant for AC and highly negative significant for CC in both years. The previous studies showed that additive gene effect was significant for AC in grape and eggplant, and additive gene action as main genetic effect for inheritance of AC were supported by higher heritability (SINGH et al., 2011; LIANG et al., 2012; SABOLU et al., 2014). However, SABOLU et al. (2014) reported a dominance gene effect for AC. In contrast, dominance effect was the main genetic effect for CC (SONG et al., 2014). In addition, a simple additive-dominance genetic model was adequate both for $\mathrm{AC}$ and $\mathrm{CC}$ in pepper fruit (LIANG et al., 2012). Our results showed that additive gene effect was the mainly genetic effect for $\mathrm{AC}$ and $\mathrm{CC}$, and additive-dominance genetic model was inadequate both for $\mathrm{AC}$ and $\mathrm{CC}$.

The decomposition of gene effects and estimation of heritability for AC and CC were listed in table 3. Total fixable gene effects was higher than non-fixable gene effects on genetic control of $\mathrm{AC}$, but the contrast result was found for $\mathrm{CC}$ in both seasons. In addition, the higher broad sense heritability and moderate narrow sense heritability for AC indicated that the trait was controlled mainly by genetic effect, and both additive and non-additive gene effects were important. However, moderate broad sense heritability and lower narrow sense heritability were detected for $\mathrm{CC}$ indicating the trait was affected by both genetic and non-genetic effect,

Table 2 - The $t$-test, scaling tests and six parameter model in a 10-Zi006 $\times 10-4438$ cross for anthocyanin and chlorophyll contents.

\begin{tabular}{|c|c|c|c|c|}
\hline \multirow{2}{*}{ Parameter } & \multicolumn{4}{|c|}{ 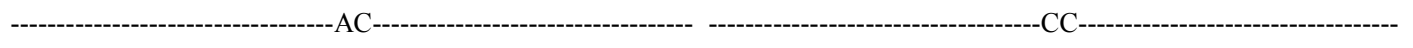 } \\
\hline & $2012 / 13$ & 2013/14 & $2012 / 13$ & 2013/14 \\
\hline$t$-value & $34.04^{* *}$ & $32.77^{* *}$ & $16.84^{* *}$ & $16.80^{* *}$ \\
\hline A & $-0.02 \pm 0.115$ & $0.14 \pm 0.176$ & $-6.51^{* * * *} \pm 0.679$ & $-8.34^{* * *} \pm 0.890$ \\
\hline B & $0.07^{* *} \pm 0.027$ & $0.07^{*} \pm 0.029$ & $6.70^{* * *} \pm 0.849$ & $7.23^{* * *} \pm 0.938$ \\
\hline $\mathrm{C}$ & $-0.83^{* * *} \pm 0.157$ & $-0.93^{* * * *} \pm 0.195$ & $-12.15^{* * *} \pm 1.275$ & $-10.63^{* * *} \pm 1.530$ \\
\hline$\chi^{2}$ & $39.25^{* * *}$ & $31.54^{* * *}$ & $305.62^{* * *}$ & $243.30^{* * *}$ \\
\hline $\mathrm{m}$ & $0.590^{* * *} \pm 0.036$ & $0.710^{* * *} \pm 0.047$ & $49.170^{* * *} \pm 0.218$ & $54.29^{* * * *} \pm 0.7812$ \\
\hline [d] & $0.900^{* * *} \pm 0.051$ & $1.130^{* * * *} \pm 0.086$ & $-2.430^{* *} \pm 0.396$ & $-3.20^{* * *} \pm 0.6491$ \\
\hline [h] & $0.205 \pm 0.179$ & $0.375 \pm 0.257$ & $11.065^{* * *} \pm 1.266$ & $8.11^{* * *} \pm 3.4279$ \\
\hline [i] & $0.880^{* *} \pm 0.176$ & $1.140^{* *} \pm 0.255$ & $12.340^{* * *} \pm 1.178$ & $9.60^{* * *} \pm 3.3838$ \\
\hline [j] & $-0.045 \pm 0.058$ & $0.035 \pm 0.089$ & $6.605^{* * * *} \pm 0.467$ & $-7.78^{* * *} \pm 0.7630$ \\
\hline$[1]$ & $-0.903^{*} \pm 0.258$ & $-1.35^{*} \pm 0.396$ & $12.530^{* *} \pm 2.033$ & $-8.49^{* *} \pm 4.2080$ \\
\hline
\end{tabular}

$\mathrm{AC}=$ Anthocyanin content; $\mathrm{CC}=$ Chlorophyll content; $\mathrm{t}$-valu $\mathrm{e}=\mathrm{t}$ test for parents; ${ }^{*} \mathrm{P}<0.05 ;{ }^{* *} \mathrm{P}<0.01 ;{ }^{* * * *} \mathrm{P}<0.001 ; \mathrm{m}=$ mean of the generation; [d] $=$ additive effect; $[\mathrm{h}]=$ dominance effect; $[\mathrm{i}]=$ additive $\times$ additive effect; $[\mathrm{j}]=$ additive $\times$ dominance effect; $[1]=$ dominance $\times$ dominance effect. 
Dai et al.

Table 3 - The decomposition of gene effects and heritability in a 10-Zi006 $\times 10-4438$ cross for anthocyanin and chlorophyll contents.

\begin{tabular}{|c|c|c|c|c|c|c|c|c|}
\hline \multirow{2}{*}{\multicolumn{2}{|c|}{ Characters Year }} & \multirow{3}{*}{$\begin{array}{r}\text { [d] } \\
0.900\end{array}$} & cts------- & \multirow{2}{*}{ Epistatic effects } & \multicolumn{4}{|c|}{------Total gene effects------- -----------Heritability----- } \\
\hline & & & \multirow{2}{*}{$\frac{[\mathrm{h}]}{0.205}$} & & \multirow{2}{*}{$\begin{array}{c}\text { Fixable } \\
1.78\end{array}$} & \multirow{2}{*}{$\begin{array}{c}\text { Non-fixable } \\
1.153\end{array}$} & \multirow{2}{*}{$\frac{\mathrm{h}_{\mathrm{B}}^{2}}{83.79}$} & \multirow{2}{*}{$\frac{\mathrm{H}_{\mathrm{N}}^{2}}{50.59}$} \\
\hline$\Delta C$ & $2012 / 13$ & & & 1.828 & & & & \\
\hline$A C$ & $2013 / 14$ & 1.130 & 0.375 & 2.525 & 2.27 & 1.76 & 83.19 & 35.56 \\
\hline \multirow{2}{*}{$\mathrm{CC}$} & $2012 / 13$ & 2.430 & 11.065 & 31.475 & 14.77 & 30.2 & 52.75 & 34.92 \\
\hline & $2013 / 14$ & 3.200 & 8.110 & 25.87 & 12.8 & 24.38 & 54.37 & 36.46 \\
\hline
\end{tabular}

$\mathrm{AC}=$ Anthocyanin content; $\mathrm{CC}=$ Chlorophylls content; Epistatic effects $=[\mathrm{i}]+[\mathrm{j}]+[1]$; Fixable components $=[\mathrm{d}]+[\mathrm{i}]$; Non-fixable components $=[\mathrm{h}]+[\mathrm{j}]+[1]$ (ignoring signs); $\mathrm{h}_{\mathrm{B}}{ }^{2}=$ Broad sense heritability; $\mathrm{h}_{\mathrm{N}}{ }^{2}=$ Narrow sense heritability.

and the additive effect and non-additive effect as well as environmental effect were important.

Analysis for twelve parameters models (Table 4) indicated additive effect [d], additive $\times$ additive effect [i], dominance $\times$ dominance effect [1], environmental effect (el) and environmental $\times$ additive effect (gdl) were significant or highly significant for genetic control of AC. the additive effect, dominance effect [d], additive $\times$ additive effect, additive $\times$ dominance effect $[\mathrm{j}]$, dominance $x$ dominance effect and environmental effect were highly significant for CC. However, the $\mathrm{m}+[\mathrm{d}]+[\mathrm{h}]$ $+[\mathrm{i}]+[\mathrm{l}]+\mathrm{el}+\mathrm{gdl}+$ gil and $\mathrm{m}+[\mathrm{d}]+[\mathrm{h}]+[\mathrm{i}]+[\mathrm{j}]+$ $[1]+$ el were the perfect model for the genetic control of $\mathrm{AC}$ and $\mathrm{CC}$ in rapeseed.

The relationships between $\mathrm{AC}$ and $\mathrm{CC}$ were calculated in $\mathrm{P}_{1}, \mathrm{P}_{2}, \mathrm{~F}_{1}, \mathrm{~F}_{2}, \mathrm{~B}_{1}$ and $\mathrm{B}_{2}$ populations with $80,78,75,418,318,156$ plants in $2012 / 2013$ and $75,66,69,301,160$ and 156 plants in 2013/2014. The negative correlations between $\mathrm{AC}$ and $\mathrm{CC}$ were obtained in $\mathrm{P}_{1}, \mathrm{~F}_{2}$ and $\mathrm{B}_{1}$ generations in two years. $\mathrm{B}_{1}$ and $\mathrm{F}_{2}$ generations was significantly negatively correlated in both years. However, no significant positive correlation were detected in $\mathrm{P}_{2}, \mathrm{~F}_{1}$ and $\mathrm{B}_{2}$ generations (Table 5). In accordance with this studies, the same relationship was detected between black and violet pepper groups (STOMMEL et al., 2014), indicating that decreasing of $\mathrm{CC}$ was due to the high concentration of anthocyanin. Fortunately, positive correlation was also observed between $\mathrm{AC}$ and $\mathrm{CC}$ in $\mathrm{F}_{1}$ generation. This result reveal that breeding of rapeseed hybrid with purple-red leaf for drought and cold stress resistance could be achieved, while CC in leaves is maintained.

Table 4 - The genotype $\times$ environment interactions for anthocyanin and chlorophyll contents in six generations of a $10-Z i 006 \times 10-4438$ cross grown in two years.

\begin{tabular}{|c|c|c|c|c|}
\hline & Full model & Fitness of model & Full model & Fitness of model \\
\hline $\mathrm{m}$ & $0.650^{* *} \pm 0.030$ & $0.650^{* *} \pm 0.029$ & $51.740^{* *} \pm 0.178$ & $51.691^{* *} \pm 0.174$ \\
\hline [d] & $1.015^{* *} \pm 0.050$ & $1.017^{* *} \pm 0.016$ & $-2.815^{* *} \pm 0.318$ & $-2.672^{* *} \pm 0.307$ \\
\hline$[\mathrm{h}]$ & $0.290 \pm 0.157$ & $0.291^{*} \pm 0.120$ & $9.545^{* *} \pm 1.016$ & $10.029^{* *} \pm 0.985$ \\
\hline [i] & $1.010^{* *} \pm 0.155$ & $1.009^{* * *} \pm 0.122$ & $10.930^{* *} \pm 0.954$ & $11.396^{* *} \pm 0.922$ \\
\hline [j] & $-0.005 \pm 0.053$ & - & $-7.195^{* *} \pm 0.367$ & $-7.03^{* *} \pm 0.358$ \\
\hline [1] & $-1.140^{* *} \pm 0.236$ & $-1.144^{* *} \pm 0.135$ & $-10.470^{* *} \pm 1.614$ & $-11.22^{* *} \pm 1.568$ \\
\hline e1 & $0.060^{*} \pm 0.030$ & $0.058^{* *} \pm 0.007$ & $2.570^{* *} \pm 0.178$ & $2.373^{* *} \pm 0.094$ \\
\hline $\operatorname{gd} 1$ & $0.115^{*} \pm 0.050$ & $0.075^{* *} \pm 0.015$ & $-0.385 \pm 0.318$ & - \\
\hline gh1 & $0.085 \pm 0.157$ & - & $-1.520 \pm 1.016$ & - \\
\hline gil & $0.130 \pm 0.155$ & $0.038^{*} \pm 0.016$ & $-1.410 \pm 0.954$ & - \\
\hline gj1 & $0.040 \pm 0.053$ & - & $-0.590 \pm 0.367$ & - \\
\hline gl1 & $--0.210 \pm 0.236$ & - & $2.060 \pm 1.614$ & - \\
\hline$\chi^{2}(\mathrm{df})$ & - & $2.17(4)^{\mathrm{ns}}$ & - & $5.66(5)^{\mathrm{ns}}$ \\
\hline
\end{tabular}

$\mathrm{AC}=$ Anthocyanin content; $\mathrm{CC}=$ Chlorophyll content; ${ }^{\mathrm{ns}}$ No significant at $\mathrm{P}=0.05 ;{ }^{*} \mathrm{P}<0.05 ;{ }^{* *} \mathrm{P}<0.01 ; \mathrm{m}=$ mean of the generation; $[\mathrm{d}]=$ additive effect; $[\mathrm{h}]=$ dominance effect; $[\mathrm{i}]=$ additive $\times$ additive effect; $[\mathrm{j}]=$ additive $\times$ dominance effect; [1] $=$ dominance $\times$ dominance effect; el $=$ environmental effect; gdl $=$ environmental $\times$ additive effect; ghl $=$ environmental $\times$ dominance effect; gil $=$ environmental $\times$ additive $\times$ additive effect; gjl $=$ environmental $\times$ additive $\times$ dominance effect; gll; environmental $\times$ dominance $\times$ dominance effect. 
Table 5 - Pearson correlation coefficients for anthocyanin and chlorophyll contents in $\mathrm{P}_{1}, \mathrm{P}_{2}, \mathrm{~F}_{1}, \mathrm{~F}_{2}, \mathrm{~B}_{1}$ and $\mathrm{B}_{2}$ generations.

\begin{tabular}{lll}
\hline Generations & $2012 / 2013$ & $2013 / 2014$ \\
\hline $\mathrm{P}_{1}$ & -0.15 & -0.19 \\
$\mathrm{P}_{2}$ & 0.16 & 0.15 \\
$\mathrm{~F}_{1}$ & 0.07 & 0.08 \\
$\mathrm{~F}_{2}$ & $-0.18^{* *}$ & $-0.12^{*}$ \\
$\mathrm{~B}_{1}$ & $-0.26^{* *}$ & $-0.26^{* *}$ \\
$\mathrm{~B}_{2}$ & -0.08 & -0.01 \\
\hline
\end{tabular}

${ }^{*} \mathrm{P}<0.05 ;{ }^{* *} \mathrm{P}<0.01$.

\section{CONCLUSION}

Inheritance of $\mathrm{AC}$ and $\mathrm{CC}$ in rapeseed leaf were not follow the simple additive-dominance genetic model, but the non-allelic interactions played an important role. In addition, $\mathrm{AC}$ was controlled mainly by genetic effect and $\mathrm{CC}$ was affected both by genetic effect and non-genetic effect. This result indicated that selection for AC in early generations would be more effective. However, selection in later generation with $\mathrm{SSD}$ /pedigree breeding methods is a tool for the improvement of CC.

\section{ACKNOWLEDGEMENTS}

The authors would like to thank Science and Technology Department of Guizhou Province and Guizhou Academy of Agriculture Sciences for their financial supports on the projects of Guizhou talent team construction [No. Qian talent team (2013) 4004] and cultivation of talents and achievements [No. Qian GZAAS CR (2014)32 and Qian GZAAS CR (2014)31]. The authors would also like to thank Suranaree University of Technology for partly supported and the technical assistance.

\section{REFERENCES}

CAVALLI, L.L. An analysis of linkage in quantitative inheritance. London: HMSO, 1952. p.135-144. Available from: <http://www. cabdirect.org/abstracts/19541603514.html?freeview $=$ true $>$. Accessed: Jan. 5, 2012.

CHALKER-SCOTT, L. Environmental significance of anthocyanins in plant stress responses. Photochemistry and Photobiology, v.70, p.1-9, 1999. Available from: <http://onlinelibrary.wiley.com.bjdgm. cn/doi/10.1111/j.1751-1097.1999.tb01944.x/epdf>. Accessed: Jan. 2, 2008. doi: 10.1111/j.1751-1097.1999.tb01944.x.

SONG, EM. et al. Genetic analysis of the antioxidant enzymes, methane dicarboxylic aldehyde (MDA) and chlorophyll content in leaves of the short season cotton (Gossypium hirsutum L.). Euphytica, v.198, p.153-162, 2014. Available from: <http://link. springer.com.zhongjivip.net/article/10.1007/s10681-014-1100-x>. Accessed: Jan. 5, 2015. doi: 10.1007/s10681-014-1100-x.
HAYMAN, B.I. The separation of epistatic from additive and dominance variation in generation mean. Heredity, v.12, p.371390, 1958. Available from: <http://www.nature.com/hdy/journal/ v12/n3/abs/hdy195836a.html>. Accessed: Jan. 5, 2015. doi: 10.1038/hdy.1958.36.

HAYMAN, B.; MATHER, K. The description of gene interaction in continuous variation. Biometrics, v.11, p.69-82, 1955. Available from: <http://www.jstor.org/stable/3001481?seq=1\#page_scan_tab_ contents $>$. Accessed: Mar. 6, 2012. doi: 10.2307/3001481.

LEE, D.W. Pigment dynamics and autumn leaf senescence in a New England deciduous forest, eastern USA. Ecological Research, v18. p677-694, 2003. Available from: <http://onlinelibrary.wiley.com/ doi/10.1111/j.1440-1703.2003.00588.x/pdf $>$. Accessed: Jan. 5, 2014. doi: $10.1111 / \mathrm{j} .1440-1703.2003 .00588$.

LIANG, Z.C. et al. Inheritance of anthocyanin content in the ripe berries of a tetraploid $\times$ diploid grape cross population. Euphytica, v.186, p.343-356, 2012. Available from: <http://link.springer.com. zhongjivip.net/article/10.1007/s10681-011-0594-8/fulltext.html>. Accessed: Dec. 08, 2011. doi: 10.1007/s10681-011-0594-8.

MANETAS, Y. et al. The interplay of anthocyanin biosynthesis and chlorophyll catabolism in senescing leaves and the question of photosystem II photoprotection. Photosynthetica, v.49, p.515522, 2011. Available from: <http://link.springer.com.zhongjivip.net/ article/10.1007/s11099-011-0061-8>. Accessed: Nov. 23, 2011. doi: 10.1007/s11099-011-0061-8.

MATHER, K. Biometrical genetics. London: Methun and Company, 1949. 102p.

MEHRTENS, F. et al. The Arabidopsis transcription factor MYB12 is a flavonol-specific regulator of phenylpropanoid biosynthesis. Plant Physiology, v.138, p.1083-1096, 2005. Available from: $<$ http://www.plantphysiol.org/cgi/doi/10.1104/pp.104.058032>. Accessed: Nov. 23, 2014.

R DEVELOPMENT CORE TEAM. R: a language and environment for statistical computing. Vienna, Austria, 2015. ISBN 3-900051-07-0. Available from: <http://www.r-project.org>. Accessed: Nov. 23, 2014.

SABOLU, S. et al. Generation mean analysis of fruit quality traits in eggplant (Solanum melongena L.). Australian Journal of Crop Science, v.8, p.243-250, 2014. Available from: <http://search. informit.com.au/documentSummary; dn=198786353988343;res= IELHSS>. Accessed: Dec. 06, 2014.

SCHABERG, P.G. Factors influencing red expression in autumn foliage of sugar maple trees. Tree Physiology, v.23, p325-333, 2003. Available from: $<$ http://treephys.oxfordjournals.org/content/23/5/325. short>. Accessed: Sept. 6, 2002. doi: 10.1093/treephys/23.5.325.

SHEN, J.X. et al. Cytoplasmic male sterility with self-incompatibility, a novel approach to utilizing heterosis in rapeseed (Brassica napus L.). Euphytica, v.162, p.109-115, 2008. Available from: $<$ http://link. springer.com.zhongjivip.net/article/10.1007/s10681-007-9606-0>. Accessed: Nov. 03, 2007. doi: 10.1007/s10681-007-9606-0.

SHIN, W. et al. Protective effect of anthocyanins in middle cerebral artery occlusion and reperfusion model of cerebral ischemia in rats. Life sciences, v.79, p.130-137, 2006. Available from: $<$ http:// www.sciencedirect.com/science/article/pii/S0024320505012798>. Accessed: Jan. 25, 2006. doi: 10.1016/j.lfs.2005.12.033. 
SINGH, A. et al. The genetic variability, inheritance and interrelationships of ascorbic acid, $\beta$-carotene, phenol and anthocyanin content in strawberry (Fragaria $\times$ ananassa Duch.). Scientia Horticulturae, v.129, p.86-90, 2011. Available from: <http:// www.sciencedirect.com/science/article/pii/S0304423811001191>. Accessed: April 2, 2011. doi: 10.1016/j.scienta.2011.03.011.

SLATNAR, A. et al. Anthocyanin and chlorophyll content during poinsettia bract development. Scientia Horticulturae, v.150, p.142-145, 2013. Available from: <http://www.sciencedirect.com/ science/article/pii/S0304423812005006>. Accessed: Dec. 17, 2012. doi: 10.1016/j.scienta.2012.10.014.

SOLECKA, D. et al. Phenylpropanoid and anthocyanin changes in low-temperature treated winter oilseed rape leaves. Plant Physiology and Biochemistry, v.37, p.491-496, 1999. Available from: <http://www.sciencedirect.com/science/article/ pii/S0981942899800540>. Accessed: Oct. 11, 1999. doi: 10.1016/S0981-9428(99)80054-0.

STOMMEL, J.R. et al. Differential inheritance of pepper (Capsicum annuum) fruit pigments results in black to violet fruit colour. Plant breeding, v.133, p.788-793, 2014. Available from: $<$ http://onlinelibrary.wiley.com/doi/10.1111/pbr.12209/abstract $>$. Accessed: Aug. 8, 2014. doi: 10.1111/pbr.12209

TANAKA, Y. et al. Biosynthesis of plant pigments: anthocyanins, betalains and carotenoids. Plant Journal, v.54, p.733-749, 2008. Available from: <http://onlinelibrary.wiley. com/doi/10.1111/tpj.2008.54.issue-4/issuetoc>. MAY 9, 2008. doi: $10.1111 /$ j.1365-313x.2008.03447.x

TOSSI, V. et al. Nitric oxide enhances plant ultraviolet-B protection up-regulating gene expression of the phenylpropanoid biosynthetic pathway. Plant, cell \& environment, v.34, p.909921, 2011. Available from: <http://onlinelibrary.wiley.com/ doi/10.1111/j.1365-3040.2011.02289.x/abstract>. Accessed: Mar. 24, 2011. doi: 10.1111/j.1365-3040.2011.02289.x.

WANG, T.Q. et al. Material breeding, heredity and utilization of purple-red leaf marker character in Brassica napus L. In: INTERNATIONAL RAPESEED CONFERENCE, 12., 2007, China. Proceedings... China: Wuhan, 2007. p.343-346. <http://gcirc.org/ fileadmin/documents/Proceedings/IRCWuhan2007vol1/343-346. pdf $>$. Accessed: Jun. 16, 2012.

WANG, Y. et al. UV-A light induces anthocyanin biosynthesis in a manner distinct from synergistic blue+ UV-B light and UV-A/ blue light responses in different parts of the hypocotyls in turnip seedlings. Plant and Cell Physiology, v.53, p.1470-1480, 2012. Available from: <http://pcp.oxfordjournals.org/content/53/8/1470. long>. Accessed: Jun. 16, 2012. doi: 10.1093/pcp/pcs088.

WARNER, J.N. A method for estimating heritability. Agronomy Journal, v44, p.427-430, 1952. Available from: $<$ https://dl.sciencesocieties.org/publications/aj/abstracts/44/8/ AJ0440080427/preview>. Accessed: Jan. 5, 2012.

WILLIAMS, C.M. et al. Blueberry-induced changes in spatial working memory correlate with changes in hippocampal CREB phosphorylation and brain-derived neurotrophic factor (BDNF) levels. Free Radical Biology and Medicine, v.45, p.295-305, 2008. Available from: <http://www.sciencedirect.com/science/ article/pii/S0891584908002098>. Accessed: Apr. 17, 2008. doi: 10.1016/j.freeradbiomed.2008.04.008.

WU, X.J. et al. Breeding of temporary all maintainer with purple leaf in oilseed rape (Brassica napus L.). In: INTERNATIONAL RAPESEED CONFERENCE, 12., 2007, China. Proceedings... China: Wuhan, 2007. p.136-139. Available from: < http://gcirc.org/ fileadmin/documents/Proceedings/IRCWuhan2007vol1/136-139. pdf $>$. Accessed: Jun. 16, 2012. 